\title{
Det moderne menneskes situation og Grundtvigs antropologi
}

\author{
Af William Michelsen
}

Det moderne menneskes situation adskiller sig fra de »gamle dages« menneskes derved, at det moderne menneske ikke kan tænke sig nogen anden solid betragtning af tilværelsen end den, der udgår fra mennesket selv - gerne alle menneskers og gerne det enkelte menneskes, gerne sin egen og gerne sine medmenneskers, men ikke en betragtning, der underordner mennesket eller menneskene under en anden og højere magt. I så henseende er allerede Kant moderne.

I denne forstand var dog også Platon og Sokrates og sofisterne »moderne«: de gjorde mennesket til alle tings udgangspunkt og målestok. De over mennesket hævede forestillinger, som Platon kaldte »ideer«, var hentede fra mennesket selv. Han - og formodentlig også Sokrates - projicerede lige så vel som sofisterne og stoikerne, omend hver på sin måde, og også Kant og de efterkantiske idealister på deres måde visse menneskelige fænomener op i en anden verden, som de kaldte »guddommelig«, men som kun var guddommeliggjort menneskelighed. Og dette gjorde de så at sige nødtvungent - fordi de havde bundet sig til at forklare alt ud fra sig selv, dvs. fra mennesket, dvs. fra deres viden om menneskene. Det samme gjorde Marx, og det samme gør psykoanalytikerne og socialpsykologerne, ja praktisk talt al moderne videnskab om mennesket og samfundet - hvad man jo ikke kan bebrejde den, eftersom den kun påstår om sig selv (dvs. for så vidt som den kun påstår om sig selv) at være viden om mennesker og menneskeliv.

I 》gamle dage - dvs. før sofisterne og før Kant og før den franske revolution - troede folk på Gud, læge såvel som lærde i almindelighed, dvs. de troede på, at de selv såvel som hele verden (levende væsener og ikke-levende ting) var blevet til og stadig opretholdtes af overmenneskelige magter eller kræfter, som vi nok kunne have nogen viden om, men ikke erkende i deres egentlige væsen med 
vor fornuft. Fornuften var et udmærket brugbart og praktisk redskab til at erkende den del af tilværelsen, som det var nødvendigt for os at kende for at leve og overleve, så længe livet rakte, men ikke bestemt til at erhverve viden om alt, eftersom der var ting, vi ikke kunne og heller ikke behøvede at have viden om, f. eks. hvordan verden var blevet til.

Det ligger i selve denne indrømmelse (at vi hverken véd eller kan vide eller behøver at vide alt), at mennesket er underordnet en overmenneskelig virkelighed, dvs. at det både hvad magt og viden angår er afhængigt af noget andet, noget ikke-menneskeligt. Man kan kalde dette andet »jorden«, »naturen«, »Gud«, »materien«, »substansen «, »Faderen«, »Den store Moder«, »magterne«, »guder《 og »dæmoner« - eller man kan kalde det »kræfter«, »energi«, »grundstoffer« og »atomer « efter hvorvidt man tænker mytologisk eller naturfilosofisk. Men spørgsmålet er i denne sammenhæng ikke, hvorvidt man tænker religiøst eller ej. Mytologi og naturfilosofi kan, hver på sin måde være udtryk for samme holdning over for tilværelsen, nemlig den, at vi er underkastet en overmenneskelig virkelighed, som først og fremmest viser sig deri, at vi er dødelige, og at vi kun i en vis (man kan mene stor, man kan mene ringe) udstrækning er i stand til at bestemme eller bevirke, hvad der sker såvel med os selv som med andre mennesker, dyr, planter og ting. Det er ifølge denne opfattelse ikke blot mennesker og af mennesker kontrollerede eller dirigerede faktorer, som i øvrigt bestemmer og bevirker, hvad der sker.

Det moderne menneske har imidlertid også (eller rettere: havde i forrige århundrede) en naturfilosofi, som adskiller sig fra »gamle dages« menneskes derved, at den tager sit udgangspunkt (ikke blot for betragtningen, men også for den viden og magt, som afgør, hvad der sker) i mennesket selv - ikke nødvendigvis i det enkelte menneske, men i den viden og magt, mennesker kan erhverve sig. En sådan naturfilosofi kan kun $i$ uegentlig forstand kaldes religiøs, hvadenten man ved religion forstår en form for »bundethed « eller ærefrygt eller ligefrem underkastelse under en eller flere overmenneskelige magter eller kræfter. For det moderne menneskes naturfilosofi eller eventuelle mytologi (som den, man finder i i 8oo-tallets romantiske digtning eller kan finde f. eks. i Hereticagruppens og anden moderne poesi) er og bliver betragtningen, når alle slør fjernes, antropocentrisk, kredsende om mennesket. Man udvider den naturlige egocen- 
tricitet $\mathrm{i}$ vor sansning af omverdenen til hele tilværelsesbetragtningen: der er ikke andet end, hvad vi med vor fornuft kan erhverve os viden om og derved, før eller senere, magt over.

Denne betragtning er efterhånden blevet os så naturlig, at vi dårlig kan sætte os ind $\mathrm{i}$, hvordan mennesker tænkte $\mathrm{i}$ »gamle dage«. Måske kan vi - ved at mindes, hvordan vi har tænkt som børn gøre os forestillinger derom. Men dét er ikke engang sikkert, eftersom opdragelsen i henved 200 år har tenderet mod at vænne børn af med at tænke sådan. Hvis man vil forstå litteratur fra tiden før Kant og den franske revolution, er det nødvendigt at sætte sig ind i den betragtning, der gjaldt $\mathrm{i}$ »gamle dage«. Men det er også nødvendigt, hvis man vil sætte sig ind i den filosofi og sagprosa, der gik ud på at modarbejde betragtningen $\mathrm{i} \gg$ gamle dage«. Dette modarbejde kaldte man ikke »moderne« før omkring I870; man kaldte det videnskabelig stræben eller simpelthen »videnskaben«. H.C. Ørsted er den mest karakteristiske ( $\mathrm{g}$ i Danmark formentlig den mest indflydelsesrige) repræsentant for denne stræben.

For Ørsted var denne bestræbelse ikke vendt mod religionen som sådan, kun mod visse overnaturlige forestillinger, som han kaldte overtro. Religion og videnskab var for ham to sider af samme sag, forudsat at religionen faldt sammen med en korrekt naturvidenskabelig opfattelse af tilværelsen. Han nærede en dyb ærefrygt for dén store sammenhæng i naturen, han gennem sin tids naturfilosofi havde fået øje for, og som den eksperimenterende naturvidenskab havde givet ham mulighed for at kontrollere. Han så det som sin livsopgave at videreføre naturvidenskabsmændenes samarbejde og give så mange mennesker som muligt forståelse af det og indblik i den store sammenhæng, som hans »totalanskuelse« havde ladet ham se og forstå. At drive videnskab var en form for gudsdyrkelse. Det er denne religiøse ærefrygt, der direkte udtrykkes i hans »Samtale om Mysticismen « fra $\mathrm{I} 807$, og som afspejles i slutningen af H. C. Andersens eventyr »Klokken«, hvor digteren taler om »Naturens og Poesiens store Kirke«.

Er en sådan betragtning og følelse ægte religiøs? - Det må efter min mening bero på, om den, der har den, derved mener sig gjort uafhængig af den natur og den tilværelse, han er en del af. I så fald må svaret være nej. - Men det er vanskeligt at se og afgøre (både hos sig selv og andre), om mennesket opfatter sig som uafhængig, selvstændiggjort, eller ej. - Det er dog et faktum, at den her 
skitserede betragtning (som Ørsted tilsluttede sig) dels bevidst, dels ubevidst har ført til en livsanskuelse, som går ud fra menneskets fornuft og betragter denne som værende i stand til - før eller senere at underlægge sig hele verden og tilværelsen, både hvad viden og magt angår. En sådan livsanskuelse kan ikke betegnes som religiøs.

Det er i denne situation, den eksistentielle religiøsitet er blevet det moderne menneskes eneste mulighed for ægte religiøsitet. For Søren Kierkegaard var H. C. Ørsteds totalanskuelse fra et religiøst synspunkt letkøbt og uigennemtænkt. Præstens opgave var ikke »eengang om Ugen at electrisere Menigheden, galvanisk bringe den til at sprætte«, men »ligesaavel som enhver Andens existerende at udtrykke, hvad han forkynder «: »... selv hvor han synes allerfjernest fra Religieusitetens absolute Fordring maa denne være tilstede, bestemme Prisen og Dommen « (Afsluttende uvidenskabelig Efterskrift ved Niels Thulstrup, i 962, s. 457).

Ja - Kierkegaard har endog på dette sted (hvor han formentlig netop hentyder til Ørsted) forestillet sig Ørsteds religiøsitet mere romantisk begejstret og begejstrende, end den var. For Ørsted var »Hele Tilværelsen eet Fornuftrige«, således lyder titelen på et af de efterladte manuskripter, som blev udgivet efter hans død.

For Ørsted var tilværelsen altså gennemtrængelig for den menneskelige fornuft, omend den endnu ikke var gennemtrængt deraf; overensstemmelsen mellem den menneskelige fornuft og naturlovene overbeviste ham om sandheden af den store sammenhæng, der fyldte ham med religiøs ærefrygt. For Kierkegaard var denne overensstemmelse religiøsiteten ganske uvedkommende. Religiøsiteten stiller en absolut fordring til det enkelte menneske - ikke om større eller mindre indsigt $\mathrm{i}$ og beundring for tilværelsens indretning, men om tro, lydighed, kærlighed. Subjektiviteten er sandheden - men ikke således at det enkelte menneskes følelser, tanker og forestillinger med centrum i det selv er sandhed, nej - i den absurde forestilling, at der er en Gud, som stiller krav til mig.

Kierkegaard - og alle moderne religiøse - måtte gribe til det absurde, måtte springe ud af den menneskelige fornufts tryllekreds, for overhovedet at komme til ægte religiøsitet.

Men hvorledes er det moderne menneske kommet ind i denne tryllekreds? Uden svar på dette spørgsmål er det umuligt for et moderne menneske at komme ud af den på anden måde end ved et sådant spring. 
Der findes et meget simpelt svar på dette spørgsmål. - Ved sine såkaldte »beviser« på Guds eksistens, ved sin bevidste eller ubevidste underordnen sig den videnskabelige tænkning, som om den var en religiøs tro, ved sin reduktion af al religion til projektioner af den menneskelige tænknings idealer, såvel etisk som videnskabeligt, har mennesket ment at kunne forstå sig selv og tilværelsen uden tro på en skaber, en overmenneskelig dommer, en herre og frelser.

Uden at indse dette er det umuligt at forstå Grundtvig. - Grundtvig regner ikke med det moderne menneske, der kredser om sig selv, men med de gamle dages menneske, der tror på Gud. - For Grundtvig er menneskets situation ikke dén udelukkende at være henvist til sig selv og til en absolut og uforståelig og uopfyldelig fordring, men dén at være skabt - at have fået tilværelsen givet af en anden - at være uløseligt afhængig af en omverden, der ligeledes er skabt, og at have en mulighed for af fri vilje at gøre, hvad det er skabt til at gøre. Da erfaringen viser, at mennesket langtfra altid gør dette erfaringen om, hvad der kaldes syndefaldet - opstår der utallige vanskeligheder for at forstå, hvordan mennesket alligevel kan nå hensigten med dets skabelse. Om løsningen af disse vanskeligheder drejer al religion sig, også Grundtvigs, dvs. kristendommen slet og ret.

For at forstå Grundtvig - og al ikke-eksistentialistisk religiøsitet - er det altså nødvendigt at opgive den krampagtige holdning, som her er kaldt »det moderne menneskes situation«. Det er nødvendigt at indse, at der er andet til end mennesket og hvad det har skabt hvilket skulde synes at være let, da det er indlysende. Men det er endvidere nødvendigt at indse, at mennesket trods alle fremskridt ikke behersker verden med sin fornuft - hvilket er vanskeligere, idet al filosofi og videnskab har en trang til at ville løse alle opgaver og problemer.

Denne tendens ligger $\mathrm{i}$ den fornuft, med hvilken mennesket er skabt, og kan derfor ikke i sig selv være i strid med skabelsen - eller med hensigten med menneskets skabelse, hvis man antager en sådan hensigt. Det kan i så fald ikke være denne tendens i sig selv, som er i strid med skabelsens hensigt, men må være en misbrug af fornuften, som hænger sammen med dens iver for at løse alle problemer. Misbrugen kan bestå i at sætte sig ud over de faktisk stillede opgaver og teoretisk forestille sig dem løst - for at tage fat på andre, mere lokkende problemer. En sådan misbrug kan føre til en fejludvikling af filosofi og videnskab, som atter kan føre til fejludviklinger i det 
menneskelige samfund. - Som en analogi kan man tænke på de vækstforandringer, hormoner fremkalder hos planter, dyr og mennesker. De har en naturgiven hensigt, men forfejler den undertiden - ja disse fejludviklinger kan bevidst fremkaldes af mennesker. På tilsvarende måde kan man betragte f. eks. tyranni, diktatur, krig, forurening, umenneskelig retshåndhævelse og børneopdragelse som forskellige fejludviklinger i det menneskelige samfund, fremkaldt ved misbrug af fornuften.

Men hverken ved nævnelse af disse eksempler eller den forudgående formulering af menneskets situation - såvel det gamle som det moderne - er der løst nogen gåder. Der er kun peget på en vej ud af den blindgyde, det moderne europæiske og amerikanske menneske og dets civilisation er kommet ind $i$.

Forudsætningen er at kende Grundtvigs og vor egen situation. Den er nemlig den samme. Grundtvig var ikke en håbløst gammeldags tænker. Han havde gennemskuet den situation, der her er opridset.

Der er imidlertid ét forhold, der væsentligt adskiller den nuværende situation fra den på Grundtvigs tid herskende tendens: naturvidenskabens stilling til de humanistiske videnskaber (herunder teologien) er væsentlig ændret. Hvor meget end Niels Bohrs holdning minder om H. C. Ørsteds, for så vidt som de begge søgte (og fandt) visse fælles træk hos naturvidenskabsmanden og humanisten, og derved, at de begge var villige til at lade sig belære af forsøgsresultater, som modsagde tidligere almindeligt antagne teorier, så var Bohrs holdning dog mere ydmyg end Ørsteds, og den skole af fysikere, han har dannet, følger ham i så henseende. Men det er svært for humanister og samfundsforskere at forstå, hvori den her omtalte holdning består.

Når en fysiker vil demonstrere dette for en humanist, plejer han at anvende et forsøg, der enten forudsætter så ekstreme forsøgssituationer, at en humanist kun med sin fantasi kan følge med, eller et forsøg, der er så simpelt, at det kun overbeviser den i forvejen overbeviste. Det drejer sig om den grænsesituation, i hvilken en lyskilde er så reduceret, at den kun udsender én proton ad gangen. Ved at indskyde polariserede glas foran et tændt stearinlys kan man bevirke, at kun lodrette lysbølger slipper igennem. Drejer man nu det ene af to således polariserede glas $90^{\circ}$, så at det kun lader vandret polariserede lysbølger slippe igennem, forhindrer man altså både lodrette og vandrette lysbølger i at passere. Dette forsøg er simpelt: der slipper 
faktisk kun meget lidt lys igennem. Men nøjes man med at dreje det andet glas $45^{\circ}$, bliver det vanskeligt at sige, hvilke protoner der passerer. $\mathrm{Ja}$ - når lyskilden reduceres til kun at udsende én proton ad gangen, bliver det endog umuligt statistisk at udregne, hvor mange - uden at forestille sig en umulig situation: $\mathrm{I}^{1 / 2}$ proton. Situationen er umulig, fordi protonen er udelelig. Under almindelige forhold (når lyskilden har normal styrke) kan man kun statistisk angive, hvor mange protoner der slipper igennem. Men det kan man til gengæld også eksakt angive, når alle forsøgsdata er kendte. - Denne situation gør det altså umuligt at forudsige den enkelte protons bane. Hvorvidt den slipper igennem eller ej, synes indetermineret.

Nogle humanister og samfundsforskere vil være tilbøjelige til at sammenligne denne situation med de komplicerede forhold, der gør det umuligt at forudsige et menneskeligt eller socialt (evt. økonomisk) årsagsforløb, og altså mene, at der er tale om praktiske forhold, som muligvis kan overvindes - f. eks. ved en anden forsøgsopstilling. Men årsagen til indeterminationen ligger i protonens udelelighed; vi har her den mindste partikel, der kan eksistere - den kan ikke deles, men under visse forhold omdannes til energi. At møde disse ganske uventede forhold har præget fysikernes holdning over for muligheden af at give en altomfattende beskrivelse af universet - og således underlægge hele tilværelsen den menneskelige fornuft.

En fysiker véd, at de forhold, han beskriver, er de relativt enklest beskrivbare i universet. Han har et sprog til at beskrive dem i: matematikkens sprog (som undertiden må udvides for at give en adækvat beskrivelse af de forhold, der skal beskrives). Men han erfarer også - f. eks. ved de antydede forsøg - umuligheden af at opfylde den klassiske fysiks krav om determination, dvs. forudsigelighed af en partikels bane, når man kender dens begyndelsessituation og de kræfter, der påvirker den, nøjagtigt. - Denne situation kendte H. G. Ørsted ikke, og den ville have overrasket ham meget; han byggede på den klassiske fysik og regnede med stoffets absolutte delelighed. For ham eksisterede kun centripetal- og centrifugalkraft, der fungerede efter rationelle love: »Naturkræfter « og »Naturtanker《 i overensstemmelse med den menneskelige fornuft. Stoffet opstod i et elektrisk felt.

Fysikkens filosofiske situation er altså en anden i 1900-tallet end den, der herskede i I8oo-tallet.

Hvad der overraskede Ørsted (og fysikerne på hans tid), var mulig- 
heden af at anskue hele tilværelsen som en sammenhæng af kraftfelter, hvori naturkræfterne virkede efter naturlove, på en måde, der lod sig beregne ved den menneskelige fornuft og udtrykke $i$ et matematisk sprog. - Hvad der overraskede Bohr (og fysikerne på hans tid) var at støde på granserne for denne anskuelse, dvs. for universets beskrivbarhed.

For at tage et andet eksempel, der sikkert er mere belysende: for Ørsted som for Kant var rum og tid anskuelsesformer, der gjorde det muligt at bestemme enhver tings plads i tilværelsen og operere med et samtidighedsbegreb, som vi ikke kan undvære i det praktiske liv. Vi må vide, hvornår toget går, for at være der på dette tidspunkt. Det er os umuligt at rive os løs fra dette samtidighedsbegreb, der forudsætter, at vi og toget befinder os på en ubevægelig jord. De konsekvenser, som Einsteins relativitetsteori har, er uforståelige for os i den forstand, at de er umulige at indarbejde i den for vort praktiske liv nødvendige tidsopfattelse med dens samtidighedsbegreb. - Jeg véd f. eks., at det er muligt at udregne resultater, som er eksakte, men absurde for min daglige og praktisk nødvendige tidsopfattelse. Jeg véd, at man opererer med reversibel tid, skønt tiden for mig er absolut irreversibel. - Og det véd fysikerne også. Det falder dem derfor næppe ind at bruge udtryk som Ørsteds: »Hele Tilværelsen eet Fornuftrige«. Det virker lige så naivt på dem som på mig.

Vel er naturen i stor udstrækning eksakt beskrivbar og bevægelser af legemer i stor udstrækning forudsigelige; erfaringen viser, at videnskaben skrider frem over tidligere grænser for vor viden. Men der findes forhold, som vor sunde fornuft hvor gerne den vil ikke kan forstå, omend de er virkelige og matematisk udregnelige.

Denne situation kan nok gøre det muligt at opfinde atombomber, gøre dem endnu stærkere og anvende dem. Den kan nok sætte os i stand til at opsende raketter, der giver os nye oplysninger om forholdene på andre kloder, og styre dem med tilstrækkelig nøjagtighed til, at de lander på et bestemt, forbavsende lille område såvel på den fremmede klode som på vor egen. Men sætter den os i stand til at beherske tilværelsen med vor fornuft? - Og har vi en tilsvarende præcis viden om det formål, vi vil eller skal arbejde os hen til med de midler, vi har fået i hænde eller rettere skaffet os?

Det er sådanne spørgsmål, der adskiller Bohrs og de nulevende fysikeres holdning fra Ørsteds og hans samtidiges.

Der er et værk i dansk litteratur, som handler om menneskets for- 
hold til naturen og dens kræfter - på Ørsteds tid: Oehlenschlägers Aladdin. Digteren omgikkes Ørsted daglig, da han udarbejdede det, så det udtrykker sikkert tanker, som de to venner var enige om. Der er et værk i svensk litteratur, der udtrykker et moderne menneskes angst over for den situation, som muligheden for at udnytte naturkræfterne har fremkaldt hos mange: Harry Martinsons Aniara. Den rolige tillid er vendt til angst for en fortsat rejse uden mål.

Det er denne situation, der har forandret naturvidenskabens stilling over for de humanistiske videnskaber, for ikke at tale om teologien og den derunder hørende etik. Når målet ikke er kendt og moralsk eller religiøst formuleret, bliver det i stedet politisk bestemt - af de kræfter i samfundet, som er de politisk stærkeste og bestemmende. Som i slutfasen af den 2. verdenskrig. Med alle de deraf følgende konsekvenser. I denne situation er fysikeren næsten for ydmyg - og vi andre for letsindige. Hvorledes er det muligt at vende tilbage til en sund udvikling mod et menneskeligt mål?

I denne situation falder der et nyt lys over den gamle strid mellem H. C. Ørsted og N. F. S. Grundtvig. - Hvor urimeligt det end kunne se ud i i 8I4, og hvor meget man end stadig må give Ørsted ret - det var urimeligt at tage en anonym forfatters misbrug af Bibelens profetier om Antikrist (på Frederik II af Prøjsen) og anvende dem på Napoleon! - så må man dog give Grundtvig ret $i$, at der truer en fare fra det forrige århundredes naturfilosofi og fra de af den afhængige ideologier, herunder fra naturvidenskaben, når den hævdes at indeholde både midlerne og målet for den fremtidige udvikling af vor kultur.

Kant mente, at målet for menneskearten, som for enhver anden dyreart, måtte være den fuldstændige udvikling af alle dens anlæg, i særdeleshed fornuften, der adskilte den fra de andre dyrearter, og at det middel, naturen ville betjene sig af for at nå dette mål, var striden (»der Antagonism《) mellem menneskets forskellige anlag $i$ samfundet. Han mente, at denne strid nødvendigvis måtte føre til et lovordnet samfund, der efterhånden omfattede hele jorden (Idee zu einer allgemeinen Geschichte in weltbürgerlicher Absicht, I 784). Det virker som en forlængelse af denne tanke, når demokratiske forfatninger nu udbredes over hele jorden og lignende beslutningsprocesser finder sted i overnationale forsamlinger (f. eks. FN). - Men ligger dette virkelig i naturen? - Ligger det ikke i en politisk tænkemåde? - Og bygger denne politiske tænkemåde ikke på en moral eller 
etik, der ifølge Kant udspringer af menneskets egen »praktiske fornuft«? - Idéhistorisk må disse spørgsmål vel besvares bekræftende. For Kant og hans samtid var der ingen strid mellem fornuft og natur, heller ikke mellem fornuft og moral, heller ikke mellem fornuft og religion.

Men er menneskets egen fornuft tilstrækkelig til at styre det? - Og har religionen kun den funktion at være en idealiseret forlængelse af de højeste etiske begreber, mennesket kan tænke sig? - Det har man faktisk antaget i både Kants og Grundtvigs samtid og eftertid. Men det er på disse spørgsmål, Grundtvig svarer nej.

Man er tilbøjelig til at mene, at Grundtvigs tanker i den grad er bundet til en billedlig, mytologisk-poetisk udtryksmåde, at det vil være umuligt at løsgøre dem fra disse billeder, hvad enten de nu stammer fra Bibelen, den nordiske eller græske mytologi eller hans egen digteriske fantasi. Nu er enhver opfattelse af usynlige og uhåndgribelige ting mere eller mindre bundet til billedlige forestillinger, som vi danner med vor fantasi. Alligevel søger vi, så godt det lader sig gøre, at skelne det virkelige fra det uvirkelige, også inden for det usynlige og uhåndgribelige. (Da hørelsen er den sans, hvormed vi meddeler os til hinanden ved sproget, og uhørlige tanker ligeledes udtrykkes gennem sproget, når vi tænker, falder skellet mellem virkeligt og uvirkeligt her sammen med det skel, vi sætter mellem virkeligt og uvirkeligt $i$ tankerne, og problemet er derfor ikke det samme ved hørelsen som ved synet og følelsen). For Grundtvig er en ting virkelig i samme grad som vi er i stand til at sanse den; han regner imidlertid ikke blot med de »ydre« sanser: synet, følelsen og hørelsen, men også med tilsvarende $\gg$ indre $\ll$ sanser, som han identificerer med $\gg$ Forestillingen« eller »Fantasien«, »Følelsen« eller »Hjertet« og »Erkiendelsen« eller »Fornuften«.

Grundtvig regner altså både med en synlig, håndgribelig og hørlig virkelighed og med en usynlig og uhåndgribelig virkelighed, der ikke blot falder sammen med det, vi tænker, men også med hvad den visioncere - og digtere er ifølge Grundtvigs poetik normalt visionære ser, og med, hvad et emotionelt bevæget menneske - det er alle levende mennesker mer eller mindre - føler. For Grundtvig er følelsen den sans, af hvilken de to andre (ligesom lugten og smagen) er udviklet, og dette gælder både den indre og den ydre følelse. - Heraf ses det, at Grundtvigs menneskeopfattelse hverken kan karakteriseres som idealistisk (spiritualistisk) eller som materialistisk (naturalistisk), 
men rummer elementer af begge antropologi-typer. Hans antropologi er et energisk og gennemført forsøg på at gøre alvor - videnskabeligt forsvarlig filosofi-af den tanke, at mennesket er »skabt i Guds billede « ( I. Mos. 1.27, jf. »i Guds lighed« Ef. 4.24). Grundtvig henviser ganske vist til Luthers fortolkning af I. Mosebog, men adskiller sig alligevel væsentligt fra Luther på dette punkt, idet han ikke er veget tilbage fra at skildre det nyskabte menneske som »et Skyggebillede af den treenige Gud, som det kan være i Tiden og Rummet«. Dette stemmer ifølge Grundtvigs betragtning med, at vi »finder« mennesket »som en saadan Trefoldighed, som Legem, Sjæl og Aand, skikket til Følelse, Erkiendelse og Forestilling « (Kort Begreb af Verdens Krønike, betragtet i Sammenhæng, I. Bind, I8 I 4, s. I 5).

For Grundtvig er sjoel og ånd altså ikke det samme, hvilket beror på, at Grundtvig retter sig efter I. Mosebog 2.7: »da dannede Gud Herren mennesket af agerjordens muld og blæste livsånde $\mathrm{i}$ dets næsebor, så at mennesket blev et levende væsen.« - Ikke i overensstemmelse med den sædvanlige fortolkning, at menneskesjælen er lig med Guds livsånde, men i overensstemmelse med Paulus's fortolkning I. Kor. 15.45: »»Det første menneske, Adam, blev til en levende sjæl; den sidste Adam blev til en levendegørende Aand.« Ånden er det guddommelige i mennesket, livet; både sjæl og legeme er menneskelige. - Det falder da heller ikke Grundtvig ind at anse det legemlige for ringere end det sjælelige - begge dele er skabt af Gud, »og ligesom vor Aand ei er til paa Jorden uden i Legemet, saaledes er der og for vor Erkiendelse ingen Sandhed uden i legemlig Skikkelse«. (Sammesteds s. I4).

Det bedst kendte udtryk for Grundtvigs menneskeopfattelse er dog de to linier fra salmen At sige Verden ret Farvel, hvor Grundtvig ligesom i forbigående røber det væsentlige og særegne i hans antropologi:

Før Døden med sin Iistap-Haand
Giør Skiel imellem Støv og Aand

- nemlig at det er Ånden, der opretholder livet i mennesket. Både sjæl og legeme er »Støv《 eller »kød « efter bibelsk sprogbrug, dvs. noget blot menneskeligt og forgængeligt ligesom dyr og planter. Men ånden er den livsånde, som Herren blæste i menneskets næsebor, så at det blev et levende væsen.

Det er denne tanke, Grundtvig i indledningen til Nordens My- 
thologi I 832 gav det dristige udtryk, at det er $\gg$ som et guddommeligt Experiment, der viser, hvordan Aand og Støv kan giennemtrænge hinanden og forklares $i$ en fælles guddommelig Bevidsthed «. - Det ser ud, som om den bibelske menneskeopfattelse er Grundtvig så selvfølgelig, at det ikke falder ham ind at polemisere mod den idealistiske opfattelse, der var aldeles dominerende i hans samtid, men i samme år som han døde, fortrængtes i dansk litteratur af den naturalistiske eller materialistiske, der stadig dominerer - nemlig da Georg Brandes i slutningen af Emigrantlitteraturen erklærede, »at Videnskaben har givet Revolutionsmændene Ret og Schelling Uret, og at vi, som leve i Charles Darwins Tidsalder, ikke antager Muligheden af en oprindelig paradisisk Tilstand og et Fald« (I. udg. s. 262, jf. I 966 s. 205). - Den sammenblanding af r. Mosebog og Schellings filosofi, Georg Brandes her tillader sig, stemmede formentlig bedre med den idealistiske menneskeopfattelse, han bekæmper, end med Darwins; men den strider ganske mod Bibelens og mod Grundtvigs.

Det berømteste udtryk for Grundtvigs menneskebegreb er formet som en protest mod I 700-tallets opfattelse af mennesket som et fornuftbegavet dyr og den deraf følgende pædagogik, der betragtede opdragelsen som en forberedelse til videnskabelig virksomhed. En sådan menneskeopfattelse og pædagogik var ifølge Grundtvig alt andet end progressiv (»fremskridende«):

»Er vi derfor saa forfængelige, at vi vil gøre vore Børn og hele Efter-Slægten til et Steen-Tryk af os i Legems-Størrelse, da giør vi os selv en stor Skam, og giør, saavidt det staaer til os, Efter-Slægten ulykkelig, fordi Mennesket er ingen Abekat, bestemt til først at efterabe de andre Dyr, og siden sig selv til Verdens Ende, man han er en mageløs, underfuld Skabning, i hvem guddommelige Kræfter skal kundgiøre, udvikle og klare sig giennem tusinde Slægter, som et Guddommeligt Experiment, der viser, hvordan Aand og Støv kan giennemtrænge hinanden, og forklares i en fælles guddommelig Bevidsthed.* (Indledningen til Nordens Mythologi 1832, Udv. Skrifter V s. 408).

Man kan med god grund stille denne menneskeopfattelse over for den, Kant udtrykker i sit lille skrift fra 1786 Muthmasslicher Anfang der Menschengeschichte, hvori han ligesom for spøg forsøger at bringe overensstemmelse mellem I. Mosebog og I 70o-tallets menneskeopfattelse (mens Grundtvig for alvor former sin menneskeopfattelse i overensstemmelse med Bibelens), eller den alvorligere forløber fra $\mathrm{I}_{74}$ Idee zu einer allgemeinen Geschichte in weltbürgerlicher Absicht, hvori han tillægger naturen den hensigt, at der efter 
mange revolutioner endelig skal opstå en »almindelig « (dvs. altomfattende) verdensborgerlig tilstand, »som det skød, hvori alle menneskeartens oprindelige anlæg vil blive udviklet«.

Kant vil næppe give Grundtvig ret i, at mennesket er en mageløs underfuld skabning, i hvem guddommelige kræfter skal kundgøre, udvikle og klare sig gennem tusinde slægter; han finder nemlig, at menneskeslægtens historie er en »uophørlig indvending « mod at betragte den jordiske skueplads som skabt af den højeste visdom. Kun tanken om en verdensstat som historiens egentlige hensigt ville ifølge Kant retfærdiggøre naturen - eller rettere Forsynet, som han tilføjer. Grundtvig tænker sig i stedet en udvikling af mennesket hen imod en enhed af mennesket og skaberen.

For Grundtvig er mennesket hverken en til legemverdenen falden sjæl - som Platon og Schelling og deres disciple forestillede sig eller et til uafhængighed af drifter og instinkt frigjort dyrelegeme hvad f. eks. Kant, Marx, Darwin, Freud og deres disciple forestiller sig - men en kun ved døden opløselig forening af et håndgribeligt legeme og en uhåndgribelig sjæl, karakteriseret ved tre ydre og indre sanser: følelsen, synet og hørelsen (som mennesket for de ydre sansers vedkommende har tilfælles med dyrene), der (ligesom lugt og smag) tænkes udviklet af følelsen. Det for mennesket særegne er altså ifølge Grundtvig: det indre syn, fantasien, den indre følelse, som han også kalder »Hjertet«, og den indre hørelse, der også kaldes fornuften. De tre indre sanser skaber ifølge Grundtvig intet; de er rent receptive. De »sanser « dvs. opfatter noget virkeligt eksisterende noget, hvis tilværelse er uafhængigt af mennesket, ganske som de ydre sanser opfatter ting i omverdenen eller på (evt. i) menneskets eget legeme.

Da en sådan gådefuld forening af synligt og usynligt, håndgribeligt og uhåndgribeligt ikke kan skabes af mennesker, må den erkendes for at være skabt af en over mennesket stående magt, som mennesket ikke kan begribe med sin fornuft, men kun gøre sig billedlige forestillinger om, adlyde og erkende i tro - om ikke med sit indre syn, så dog med sin indre følelse (hjertet) og sin indre hørelse.

Når mennesket ikke vil erkende denne ubegribelige magt ved troen, men i stedet vil styre sig selv (og andre mennesker, ja hele verden), forvirres eller forvanskes dets selverkendelse og omverdenserkendelse. - Det er ifølge Grundtvig dette »syndefald «, som bevirker alle menneskets illusioner. 
Det her skitserede menneskebegreb går, som det vil ses, langt tilbage i udviklingen af Grundtvigs tankeverden. Men det er blevet til efter udarbejdelsen af hans første Verdenskrønike fra 1812 og hans forsvarsskrift for den, Krønikens Gienmæle, der udkom i juli I8I3. Det første udkast dertil findes i det af Hal Koch udgivne manuskript $\mathrm{Om}$ Menneskets Vilkaar, hvis begyndelse er dateret Io. oktober I8I3 (Værker i Udvalg II s. 240-270, jf. min omtale deraf i Nordisk tidskrift 1946). Den første fremstilling af sit menneskebegreb, Grundtvig selv har udgivet, findes i hans anden Verdenskrønike fra I8I 4, som er citeret ovenfor. Sammenhængen mellem Grundtvigs tanker og samtidens psykologi er behandlet af Villiam Grønbæk i hans bog Psykologiske Tanker og Teorier hos Grundtvig ( I95I), der inddrager en del vigtigt manuskriptmateriale. Også forholdet mellem disse tidlige skrifter og Grundtvigs senere digtning - især hans salmedigtning - er behandlet af Grønbæk. Der savnes dog endnu en nærmere redegørelse for den udførelse af sine tanker om mennesket, Grundtvig har givet i tidsskriftet Danne-Virke fra 1816-18ı og den (stærkt reviderede) anvendelse deraf på menneskets historie, der foreligger i hans Udsigt over Verdens-Krøniken, fornemmelig i det Lutherske Tidsrum, hans tredie Verdenskrønike, udgivet 18 I 7. Først i disse arbejder fremtræder Grundtvigs kristne antropologi og historiefilosofi som et alternativ til den samtidige idealistiske filosofi og teologi. 